\title{
The education and training of civil engineers: a review of the Chilver proposals
}

\author{
P. ETHERINGTON
}

Mr G. F. Hawker, Consulting Engineer

Having read the Paper, it occurred to me to compare the system in force in the early 1950s and that envisaged after Chilver is implemented. The result was interesting (see Table 1).

43. At both periods AMICEs must have practical experience as Graduates before sitting the PI or PE1, and further experience and responsibility are needed before transfer to MICE ( 5 years in the 1950s, 3 years in the 1990s).

44. What, then, will Chilver have achieved? I suggest only:

(a) exclusion of Students/Graduates who have not been through a full-time academic course to get a degree;

(b) a saving of 2 years' experience between AMICE and MICE;

(c) the introduction of transfer from AMICE to MICE by exam (PE2).

In particular, AMICEs must still carry responsibility immediately after election, just as before.

45. I conclude that all that has happened is that the old grades of membership will remain exactly as they were in function and qualification, but that AMICEs are now to be deprived of professional status. The only compensation is the addition above the old, highly prestigious grade of Member of one-or perhaps two-levels of 'eminence', partly to satisfy the Privy Council (who know nothing of engineering in any event) and, one suspects, partly to remedy this miasma of self-doubt which seems to have afflicted the profession of recent years.

Table 1. Grades of membership

\begin{tabular}{|c|c|}
\hline Early 1950 s & Early 1990 s \\
\hline $\begin{array}{l}\text { Student (sufficient GSC passes) } \\
\text { Graduate ('Student' + degree or ICE } \\
\text { Exam Parts } 1 \text { and 2) } \\
\text { AMICE (Graduate + Prof. Interview) } \\
\text { MICE (AMICE + experience and respon- } \\
\text { sibility) }\end{array}$ & $\begin{array}{l}\text { Student (sufficient GCE passes) } \\
\text { Graduate ('Student' + degree) } \\
\text { AMICE (Graduate + PE1) } \\
\text { MICE (AMICE = experience and re- } \\
\text { sponsibility + PE2) } \\
\text { FICE (MICE + 10 years + 'eminence') } \\
\text { Membership of Prince Philip's } \\
\text { Fellowship of Engineers (?? = } \\
\text { 'super-duper eminence'?) }\end{array}$ \\
\hline
\end{tabular}

Paper published: Proc. Instn Civ. Engrs, Part 1, 1977, 62, Nov., 643-653. 
46. Chilver would thus appear, from this viewpoint, to be a complete waste of time and effort. To those who would argue that standards must be raised, I would reply that Chilver does not do this; if academic respectability is the goal I would point out that while the Chartered Engineer demeans himself with 'mud on his boots', conventional academics will refuse to accept him on equal terms; if recognition within the Common Market is sought, I would merely state the obvious: that such matters will be settled as part of a purely political deal, if at all, and that in any event no Frenchman will ever accept an Englishman as being a cultural equal-although we all know the opposite is all too often the case.

47. The pity of it all is that the bright youngster will now look upon a career as a Chartered Engineer as taking far too long to acquire, and go elsewhere, to the lasting disadvantage both of the ICE and the country as a whole. The remedy? Simply restore corporate status to AMICEs so that those who have the minimum of 3 years' experience since graduating can qualify then and, if they wish, stop there as fully fledged Chartered Engineers, as in the 1950s. If that were done, the idea of transfer to MICE by examination certainly appeals; the only other change I would seek would be once more to open up the path to corporate membership to those taking the 'hard way', and bypassing the academic first degree.

\section{Mr P. G. Whyatt, Rio Tinto Zinc}

The Paper once again focuses attention on the restrictive nature of the Chilver Committee's report and demonstrates that the work of the Chilver Implementation Board (CIB) has thus far, in its attempt to make the package more palatable to its critics, only proposed minor changes in detail without considering the possible benefits of some wider reconsideration.

49. The Chilver Report $(\$ 3.12 \mathrm{a})$ defines chartered engineers as those who ' $\ldots$ have standards of education which fit them to occupy positions carrying ultimate responsibility for design, construction and management in all spheres of engineering' and further states $(\$ 3.20)$ that there exists ' . . . a surplus of chartered engineers, some of whom carry out work more appropriate to technician engineers', adding (\$3.24) ' . . . the committee's view is that the standard of membership of the Institution should be raised, with a probable reduction in the number of chartered engineers and an increase of technician engineers .... However, somewhat later on (\$4.4), “The committee urges the Institution to take determined action to draw the attention of society, and of able and adventurous youngsters in particular, to the intellectual and practical attractions of a civil engineering career.'

50. What Chilver thus explicitly says is that there appear to be too many chartered civil engineers (i.e. persons whose qualifications demonstrate their fitness for top management posts) and insufficient technicians (i.e. people who perform engineering tasks), and that this situation should be remedied as far as chartered engineers are concerned by raising the requirements for chartered status, especially the educational requirements, whilst maintaining the attractiveness of those opportunities which do exist to the brightest youngsters.

51. For practical purposes there are only two routes laid down by which corporate membership can now be attained:

(a) suitable school attainment followed by a suitable degree course and suitable experience;

(b) direct entry for mature engineers (over 40 years of age) of significant standing.

There is no bridge, either currently or proposed, by which a person of technician grade can become chartered, other than by taking a full-time or sandwich degree course.

52. That there exists a wide spectrum of opinion regarding the status of the technical grades can be seen by reading through the summary of written opinions submitted to the ICE Chilver Committee (which is filed in the ICE library). Of these opinions, for example, that referenced as no. 59 reads 'much of the training of a chartered engineer is, 
and should be, to carry out technicians' work and most graduates work as technicians in their early employment, whether they later obtain chartered employment or not. This leads to the conclusion that technician status is one step on the route to chartered status (whether or not, to many, it should be the final step).' Opinion referenced as 62a reads 'There is concern about those who may prove worthy of the status of C.Eng, but are prevented from attaining it because they are not graduates and are therefore classified as T.Engs.' Opinion referenced as 69 reads, in part, 'It is unfortunate that technicians are organized into a separate society . . . .

53. What is undoubtedly unfortunate is that either intentionally or unintentionally the present and proposed arrangements which separate corporate members from the technician grades also effectively serve to divide those who can from those who cannot. And the description 'technician engineer' appears (whether intended or not) to describe one who cannot become a chartered engineer-and who is therefore limited in salary, job opportunity and in the respect afforded by his or her employer. In many cases it might well be that a person could be better off without any paper qualification at all than with the essentially limiting appellation of 'technician engineer'. While many youngsters do feel that chartered status offers them '... the intellectual and practical attractions of a civil engineering career', the numbers presenting themselves for the technician interviews have dropped from 190 in 1975 to 170 in 1976 and to 122 in 1977 (and that those who do qualify as technicians do not all feel that they receive a proper reward for their attainment is clearly seen from recent letters to New Civil Engineer).

54. It would seem reasonable therefore, since in any case almost all engineers who finally achieve chartered status do spend a considerable amount of time during their early years as technicians and technician engineers, that one route to corporate membership could, and should, be through the technician and technician engineer line.

55. This could be effected without any drop in standard from the CIB proposals whatsoever by a series of examinations and suitable training and experience determined by the ICE forming a bridge which it would be practical and reasonable for a person of relatively mature age, albeit less than 40 , to cross without being obliged to abandon his employment (and possibly imperil the welfare and standard of wife and family) in order to undertake a full-time degree or sandwich course.

56. In this way the position of technician engineer would cease to be 'top of nothing' and would no longer constitute a natural ceiling on salary and promotion-both employer and employee being aware that future progress would be both possible and practicable. There would be additional incentive for youngsters initially fearful (or due to circumstance unable to take advantage) of a degree course, there would be a 'second chance' for the late developer, and the technician grades would appear generally more attractive to young people of school and school-leaving age.

\section{Mr W. P. Winston, Consulting Engineer}

My comments "relate to $\$ \S 25-31$ : 'Practical training'. The Chilver proposal is that practical training should be under a supervising civil engineer (SCE) for a minimum period of 3 years. In my experience this form of training does not match the organization of two fields of engineering. One such field is oil production work, for instance in the North Sea. To illustrate, the Piper Field was discovered in January 1973, and came on stream with a terminal in the Orkney Islands in December 1976. When a large project is implemented at this speed there is little room for training.

58. The other field of engineering is one in which I worked some years ago, namely engineering in a less developed country than the UK. In this field a number of factors restricted the scope to provide training: programmes were large in proportion to professional staff; construction sites were remote from design offices; professional staff commonly were mobile and long tenure of a post was uncommon.

59. Thus in these two engineering fields the scope for SCEs and hence for providing training is restricted. Trainees may find this situation difficult to accept. It is suggested 
these fields of engineering are sufficiently important to justify better training arrangements for those who wish to work in them.

60. The Chilver Report proposed $(\$ 5.20)$ that a Master's degree from a UK university, by research or advanced course, should count in lieu of one year's practical training. It is suggested this may be a way of providing some practical training in the two fields of engineering mentioned above.

\section{Mr H. R. Boyce, Rendel Palmer and Tritton}

As a professional institution seeking to attain greater recognition by the public, the ICE should require a higher standard of engineers at the age of 26 , and not a continuation of an average standard from 26 until the age of 31 , that is 9 years after graduation, and then for the rest of their lives. Mr Etherington's summary of the work so far undertaken by the CIB is opportune because I consider that the proposals set out will not lead to an improved standard.

62. I do not intend to comment on the merits of a straight or a sandwich degree course and any period of the latter that should be counted towards a graduate's experience. Nor do I intend to comment upon a 3- or 4-year course. My concern is the practical training as set out in $\$ \$ 25-34$ (Fig. 1).

63. The present training is stated, in $\$ 25$, to have been 'carefully specified' in ICE 43. I disagree. Some 20 years ago the regulations were, I think, a 2-year agreement to be followed by 1 year, giving a minimum period of 3 years before the Professional Interview could be taken. The regulations further called for the 3 years to include a minimum of 1 year's design experience and 1 year's site experience, the balance of the period being optional.

64. There is no such provision in ICE 43, so it cannot be said that training guidance is carefully specified. Neither is there any indication of acceptable periods within the future 3-, 4-, 5- or 6-year periods referred to in $\$ 25$ and 27.

65. There is a contradiction in the proposals, because in $\$ 25$ it is stated that graduates will be required to undergo a minimum period of training which will be called 'approved training' under agreement, and having made this 'positive' statement, there follow, in 827 , many exceptions. What is the young graduate to do? He may go under agreement or take a chance and take PE 1 after $3,4,5$ or 6 years; in any case he has $6-9$ years ahead of him, unless he comes under the proviso in the last line of $\S 33$.

66. The CIB eases this by remarking, according to $\S 28$, that the new regulations will not be 'penal' because candidates not under agreement took 2 years longer after leaving college to take the Professional Interview than those who were under agreement. This is a wrong approach.

67. The existing rules permit the Professional Interview to be taken by an engineer of 24 (and I know of three recent cases), but I think it may be said that it is based on the expected attainment of a graduate at the age of about 25 . If a candidate delays until he is $\mathbf{2 7 - 3 0}$, then a higher standard should be adopted for such a candidate. A foreman or an inspector expects a more mature approach and answers to constructional problems from an engineer of that age than one of 25 . A client or an outside authority expects a more reasoned approach to design or planning problems. I was not surprised, therefore, when an engineer of 30, whom I know, failed recently. The interviewers he met clearly held the views that I have expressed.

68. The CIB is not encouraging a higher standard amongst engineers by their long and drawn-out procedure; they are simply prolonging the period in which mediocrity prevails. What is required is a higher standard not at the age of 30 , but at the age of 25-26, and if this were achieved, then higher standards at 30 would automatically follow. If the terms of reference for PE2 ( $\S 34)$ were adopted straight away for the present Professional Interview, then the proposed PE2 interview would be unnecessary.

69. I disagree entirely with the views set out in $\$ 28$. To replace the present Professional Interview by one that is rather less formal is something that will be hard to do. In my view what is required is a more formal and vigorous interview where a candidate 


\begin{tabular}{|c|c|c|c|c|c|c|c|c|c|c|}
\hline $\begin{array}{l}\text { Year after } \\
\text { graduation }\end{array}$ & 1 & 2 & 3 & 4 & 5 & 6 & 7 & 8 & 9 & \\
\hline & PRES & ENT & RE C & $U 1 R$ & MEN & s & & & & \\
\hline & UNDER A & REEMENT & & & & & & & & \\
\hline & 3 years & & & PI & & & & & & \\
\hline & NOT UND & R AGREEM & ENT & & & $\cdot$ & & & & \\
\hline & 4 years & & & & & & & & & \\
\hline & & & & & PI & & & & & \\
\hline & PROP & OSED & RE & UI $R_{1}$ & $M E N$ & $s$ & & & & \\
\hline \multirow{3}{*}{$\begin{array}{l}\text { Chilver reference } \\
\text { Para } 25, \text { lines } \\
5 \text { and } 6 \\
\text { and para } 33 \text {, } \\
\text { line } 11\end{array}$} & UNOER A & REEMENT & & & & & & & & \\
\hline & \multirow{2}{*}{\multicolumn{3}{|c|}{$\begin{array}{l}\text { Will be required to } \\
\text { undergo a minimum of } \\
\text { - } 3 \text { years training } \\
\text { called approved } \\
\text { training }\end{array}$}} & & & PE2 & & & & \\
\hline & & & & PE1 & OR & $O R$ & & & & \\
\hline \multirow{6}{*}{$\begin{array}{l}\text { Para } 27, \text { line } \\
10 \text {, and } \\
\text { para } 33, \\
\text { iine } 11\end{array}$} & NOT UND' & R AGREEM & & & & & & & & \\
\hline & $\begin{array}{l}\text { One tho } \\
\text { good exp }\end{array}$ & $\begin{array}{l}\text { has had } \\
\text { erfence }\end{array}$ & $x$ cept & onally & & & & & & \\
\hline & 3 years & & & PEI & $\begin{array}{l}P E 2 \\
O R\end{array}$ & $O R$ & 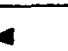 & & & \\
\hline & $O R 4$ yeg & & & & PET & PE2 & & & & \\
\hline & & & & & & $O R$ & $O R$ & & & \\
\hline & OR 5 yes & & & & & PEI & PE2 & & & \\
\hline & & & & & & & & OR & & \\
\hline \multirow[t]{2}{*}{ Para 27, line 3} & Unusual1 & good e: & perien & not & & & & & & \\
\hline & 1.inked & trainit & & & & & PEI & PE2 & & \\
\hline \multirow{2}{*}{ Para 27, line 7} & One who & is unabl & to of & ain & & & & $\mathrm{OP}$ & $O R$ & 4 \\
\hline & approve & trainin & & & & & & OR & OR & \\
\hline \multirow[t]{2}{*}{ Not listed } & One who & loes not & try tc & & & & - & & & \\
\hline & obtain & proved & rainir & & & & $\cdot$ & & & \\
\hline Age & $21-22$ & & & & & & $27-28$ & & & $30-31$ \\
\hline
\end{tabular}

Fig. 1

has to show that he has acquired not just a reasonable knowledge of most of the topics listed (nine in number) in the Training Record (p. 2, \$3), but a good or sound knowledge. A candidate for the Higher Technicians' qualifications has an interview lasting, sometimes, several hours, so that the present 20 minutes for the Professional Interview is comparatively easy.

70. If a candidate has been under agreement and it is clear from his Training Record that it has been written up and dated at one or possibly two sessions during the 3 years, then the candidate has not made best use of his agreement, and the Institution should not send his application to the interviewers if the 3-year period since leaving college is an essential qualification for his interview. Again, if interviewers had a candidate's reports and comments by the Training Officer, then they could see whether the candidate had followed up references or studied matters and raise questions on such points; they could see whether his style of reporting and his English had improved.

71. I accept that, if the existing Professional Interview were continued with a stricter 
approach, incorporating the matters in $\$ 68-70$, the CIB might consider that the present 3- and 4-year periods would have to be made $3 \frac{1}{2}$ years and $4 \frac{1}{2}$ years.

72. It may be said that there are slow developers $(\S 14)$, but the Institution cannot have those who are slow starters all their lives; surely if a candidate has obtained a degree after 3 years' study, he is moving faster than when he left school for college, and he should be able to continue to improve his standards and increase his knowledge, possibly more towards the practical side of his work, in the 3 or 4 years after leaving college. (I have only referred to men because I have found that young ladies who have been graduates under agreement had a good balanced education and good $A$ levels.)

73. Lastly, there is no mention in the Paper of the cost of the proposals. For those who may not have read the proceedings of the 1976 conference on Civil Engineering Education and Training ${ }^{14}$ the following is quoted:

'Amid increasingly heated discussion on the subject of the possible imposition by the Institution of this levy on employers providing satisfactory training, the President, Sir Norman Rowntree, drew the session to a close.'

The levy referred to was $£ 20 /$ graduate per year, to be paid by those bodies and firms undertaking training, which is for the good of the whole profession, to cover the costs incurred by the Institution. Is it fair, in principle, that those who are prepared to undertake training should have to pay a levy to an outside body for the benefit of those who are not?

Professor R. J. Cornish. Allott and Lomax

In Appendix $1 \S 3$ it is stated that subjects such as economics, politics and law are needed to 'develop an awareness of the importance of personal judgement', implying that structural engineering, soil mechanics etc. do not have this important property. It is time that this ancient heresy was abandoned. Any subject can be taught in an authoritarian or a liberal way; bad teaching is not the preserve of the scientists and technologists.

\section{Mr Etherington}

Mr Hawker draws an interesting comparison between the various grades of membership which existed in the 1950s and those which are planned when the Chilver implementation commences. His suggestion that the new grade of Associate Member should be included amongst the chartered grades has had many recent advocates, most of whom view with some concern the possible adverse future effects of the present requirements by many overseas governments that all UK staff working on their projects must be corporate members.

76. The 'hard way' of achieving acceptable academic qualifications, which both Mr Hawker and Mr Whyatt see as now closed, fortunately still exists. The route has become rather more difficult. Candidates who pass the CEI examinations and those who obtain a part-time degree in civil engineering (two courses currently exist) will satisfy the ICE requirements. However the existence of courses for these qualifications depends very much on the clear demonstration of a sufficient demand by suitably qualified candidates who have appropriate academic potential. Despite some quite strong pleas from many quarters for academic 'bridges' it is not easy for colleges to be sure that sufficient real demand exists to extend the number of these courses.

77. Mr Whyatt's comments concerning the need to establish an education and training framework which encompasses both the technical and the professional staffs, within the industry are welcome and they support the view which I expressed in $\S 42$.

78. Mr Winston draws attention to some particular situations in which available training may not fit into the prescribed pattern. It is probable that other similar situations exist and in all such circumstances I am sure that the guidance of the ICE Training Officer should be sought at or before the commencement of the particular training period. 
79. The proposal to which Mr Winston refers in the Chilver Report concerning the acceptance of higher degrees in lieu of part of the practical training period has much merit and I hope that it will be included in the new ICE $43^{13}$ when it is redrafted to incorporate the changes which are necessitated by the Chilver package. It is also to be hoped that the information which Mr Boyce seeks $(\$ 64)$ in respect of future practical training requirements will be provided in the same document.

80. The diagram of the various practical training patterns (Fig. 1) which $\mathrm{Mr}$ Boyce has prepared is most useful. The route to Associate Membership for the large majority of candidates is expected to be via approved training but Mr Boyce correctly points out that other methods will not be precluded.

81. The reservations which $\mathrm{Mr}$ Boyce expresses about the proposed function and style of the new PE1 and PE2 may appear to be less significant if the objectives of the examinations are viewed jointly. These two examinations include scrutiny of the various training reports, the candidate's essay, the candidate's submitted drawings etc. Thus-including the two interviews-the examinations will enable a thorough assessment of each candidate's technical and professional competence to be made. The Chilver Committee ${ }^{10}$ emphasized that the ICE has a duty to ensure that those who enter Membership are civil engineers of undoubted competence and that a candidate will not be able to present real proof of professional competence until he reaches his late 20 s or even later. This principle was embodied in the CIB recommendations for PE2.

82. Mr Boyce's reference to the controversial nature of the training levy draws attention to an anomaly which is difficult to avoid but $I$ have no doubt that the methods adopted for recouping the costs of the Chilver proposals will be carefully reviewed from time to time by the ICE. Perhaps the design of the examination fee structure for PE1 will reflect the training experience background of individual candidates.

83. The implication that engineering subjects do not lead to the development of 'an awareness of the importance of personal judgement' is referred to by Professor Cornish with reference to Appendix $1, \$ 3$ (ICE degree course guidelines). I am sure that all engineers (and, in particular, engineering academics) will agree with Professor Comish's views. I believe that the wording of Appendix 1 in this case is insufficiently precise but, in all other respects, I find the ICE guidelines to be acceptable. 